\title{
Chemical components, pharmacological properties, and nanoparticulate delivery systems of Brucea javanica
}

REVIEW

This article was published in the following Dove Press journal:

International Journal of Nanomedicine

31 December 2012

Number of times this article has been viewed

\author{
Meiwan Chen ${ }^{1, \ddagger}$ \\ Ruie Chen ${ }^{1, \neq}$ \\ Shengpeng Wang' \\ Wen $\operatorname{Tan}^{\prime}$ \\ Yangyang $\mathrm{Hu}^{\prime}$ \\ Xinsheng Peng ${ }^{2}$ \\ Yitao Wang'
}

'State Key Laboratory of Quality Research in Chinese Medicine, Institute of Chinese Medical Sciences, University of Macau, Macau, China;

${ }^{2}$ School of Pharmaceutical Sciences, Guangdong Medical College,

Dongguan, China

¥These authors contributed equally to this work
Correspondence: Xinsheng Peng School of Pharmaceutical Sciences, Guangdong Medical College, I Xincheng Road, Songshan Lake Science and Technology Park, Dongguan, China, 523808, China Tel +867692289656I

Fax +8676922896560

Email pxsgz@yahoo.com.cn

Prof.Yitao Wang, Institute of Chinese Medical Sciences, University of Macau,

Av. Padre Tomas Pereira S.J.,

Taipa, Macao Special Administrative

Region, China

$\mathrm{Tel}+8538397469$ I

Fax +853 2884 । 358

Email ytwang@umac.mo

\begin{abstract}
Brucea javanica has demonstrated a variety of antitumoral, antimalarial, and anti-inflammatory properties. As a Chinese herbal medicine, Brucea javanica is mainly used in the treatment of lung and gastrointestinal cancers. Pharmacological research has identified the main antitumor components are tetracyclic triterpene quassinoids. However, most of these active components have poor water solubility and low bioavailability, which greatly limit their clinical application. Nanoparticulate delivery systems are urgently needed to improve the bioavailability of Brucea javanica. This paper mainly focuses on the chemical components in Brucea javanica and its pharmacological properties and nanoparticulate formulations, in an attempt to encourage further research on its active components and nanoparticulate drug delivery systems to expand its clinical applications. It is expected to improve the level of pharmaceutical research and provide a strong scientific foundation for further study on the medicinal properties of this plant.
\end{abstract}

Keywords: Brucea javanica, chemical components, pharmacology, nanoparticulate delivery systems

\section{Introduction}

Brucea javanica, the ripe fruit of Brucea javanica (L) Merr (Simaroubaceae), was first mentioned in the Chinese medical monograph named Compendium of Materia Medica published in the sixteenth century. ${ }^{1}$ It mainly exists in the tropical and subtropical zones of China, including Guangdong, Guangxi, Yunnan, and Fujian. The fruit of the Brucea javanica plant is characteristically ovate in shape, hard, and slightly apiculate at the apex with an approximate length of 6-10 $\mathrm{mm}$ and diameter of 4-7 $\mathrm{mm}$. It is covered with protuberant reticulation and usually turns black or brown when ripe. Generally, the fruit is harvested in autumn and dried after removal of impurities. ${ }^{2}$

Actually, Brucea javanica is regarded as cold character and bitter taste, what laid the foundation for its various pharmacological properties. In Chinese medicine, Brucea javanica is characterized as an antipyretic and detoxifying plant, and widely used in the treatment of lung, prostate, and gastrointestinal cancer, and has potent antimalarial, anti-inflammatory, and antiviral effects, with low toxicity. Modern pharmacological research has demonstrated that tetracyclic triterpene quassinoids are the active ingredients in Brucea javanica, ${ }^{3,4}$ and that the potential mechanism for antitumor efficacy lies in induction of apoptosis and decreasing cell proliferation by reducing expression of the Bcl-2 gene. ${ }^{3,4}$ Brucea javanica also enhances immune function. ${ }^{5}$

Increasing attention has been paid to the remarkable antitumor activity of Brucea javanica in recent years. In this paper, we discuss the chemical components of this 


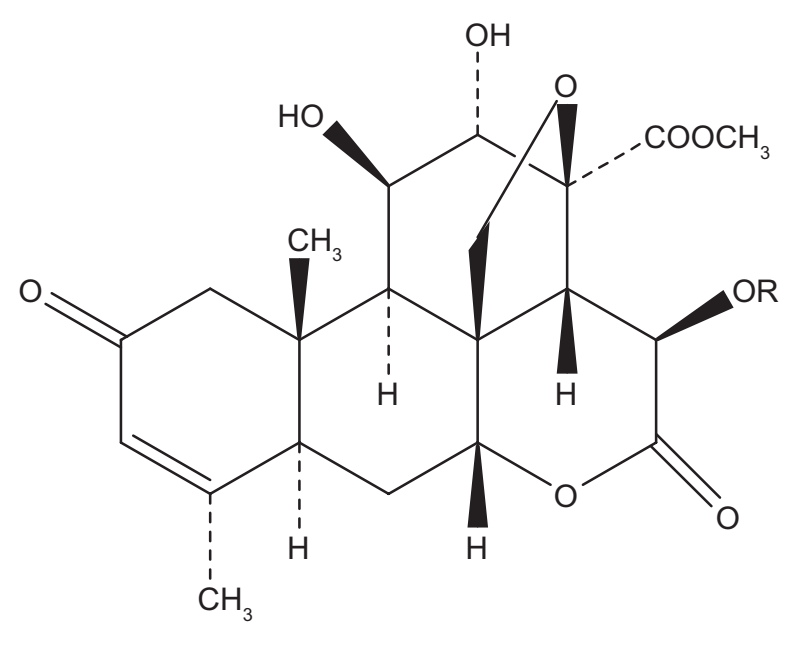

Figure I Basic structure of quassinoids.

medicinal plant, its pharmacological actions, and the prospect of developing nanoparticulate drug delivery systems, by presenting a summary of the relevant published literature on the active components of this plant and novel drug delivery systems containing Brucea javanica.

\section{Chemical ingredients}

Ever since the quassinoid compounds were first separated from Brucea javanica in 1967, more and more scientists have focused their research on the active ingredients of this plant and its antitumor activity. ${ }^{6}$ During recent decades, with the help of modern analytic methods, such as ultraviolet and infrared spectroscopy, nuclear magnetic resonance, high-performance liquid chromatography, and mass spectroscopy, much progress has been made. Researchers have now isolated several natural components from Brucea javanica. These include the tetracyclic triterpene quassinoids, ${ }^{7}$ anthraquinone, olein, oleic acid, linoleic acid, ${ }^{8}$ pregnane glucosides,, 10 and sesquiterpenes. ${ }^{11}$ In particular, tetracyclic triterpene quassinoids are the main active ingredients of Brucea javanica with remarkable antitumor activity. The basic structure of the quassinoids is shown in Figure 1. It is based on a five-atom ring of $\mathrm{C}_{8}-\mathrm{CH}_{2}-\mathrm{O}-$ $\mathrm{C}_{13}$, and is formed by three six-atom rings and a lactonic ring. According to recent research, the quassinoids have acted effectively in the treatment of several diseases. For instance, bruceoside A has good efficacy in leukemia and brusatol amarissima exert significant anti-inflammatory activity. ${ }^{12}$ The quassinoids contain bruceine A, B, C, D, E, F, G, H, and I (Figure 2), ${ }^{13,14}$ brusatol A, ${ }^{15}$ dihydrobrusatol $\mathrm{B},{ }^{16}$ bruceoside A, B, C, D, E, F, G, I, J, K, L, P, and S
(Figure 3), ${ }^{17-23}$ brusatol amarissima E2-glucosidase, ${ }^{13}$ brusatol ketoacid, and bruceen. ${ }^{24}$

\section{Pharmacological effects Antitumor activity}

Brucea javanica has been shown to have a variety of pharmacological actions, the most remarkable of which is its antitumor activity. Brucea javanica extract has shown a strong antitumor effect in S180 cells, with $24.6 \%$ inhibition of cell proliferation at high doses, while intermediate and low doses can prolong longevity by approximately $20 \%$ in tumor-bearing mice. ${ }^{25}$

Oleic acid, linoleic acid, and tetracyclic triterpene quassinoids all have antitumor activity, especially in lung, liver, ovarian, and cervical cancers. Brucea javanica inhibits cell proliferation by regulating the cell morphology and cycle, controlling apoptotic gene expression, and altering the process of cellular immunity. ${ }^{5}$ The detailed antitumor mechanisms are summarized as follows. Brucea javanica can reverse drug resistance in tumor cells by altering P-glycoprotein on the cell membrane. For example, when drug-resistant ovarian cancer cells were exposed to an oily emulsion containing Brucea javanica, there was a dramatic decrease in the number of drug-resistant cells. ${ }^{26}$ Brucea javanica can also inhibit the activity of topoisomerase II, thereby affecting DNA synthesis, leading to cell cycle arrest and apoptosis, eg, G0/G1 cell cycle arrest induced by Brucea javanica oil in hepatoma cells. ${ }^{27}$ Further, cell cycle arrest and inhibition of DNA synthesis after Brucea javanica oil treatment was seen in the human SGC-7901 gastric carcinoma cell line, indicating apoptosis. ${ }^{28}$ Meanwhile, a recent study has also provided strong evidence that Brucea javanica oil can induce apoptosis of cells via activation of caspase- 8 and modulation of apoptosis-related proteins in human acute myeloid leukemia cell lines. ${ }^{29}$ Generally speaking, patients with cancer are at risk of immunocompromise as a result of treatment with chemotherapeutic drugs. However, when used in combination with Brucea javanica, the safety and efficacy profiles of chemotherapeutic drugs improved, resulting in better immune function and quality of life in patients with late-stage lung cancer, mainly via increasing levels of $\mathrm{T}$ cells and natural killer cells. ${ }^{30}$

\section{Anti-inflammatory activity}

Traditionally, Brucea javanica has been used to treat amebic dysentery. Recent research has confirmed that Brucea javanica is also effective for malaria and other diseases with a parasitic 


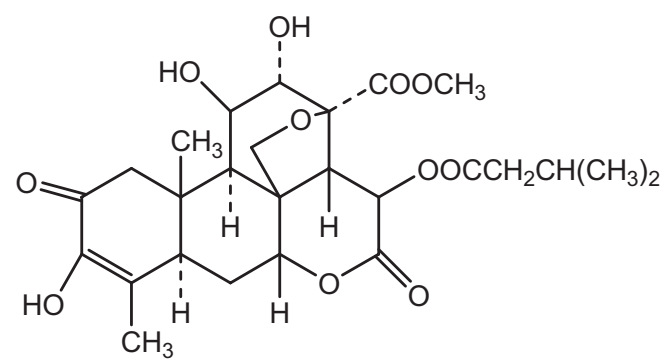

Bruceine $\mathrm{A}^{48}$

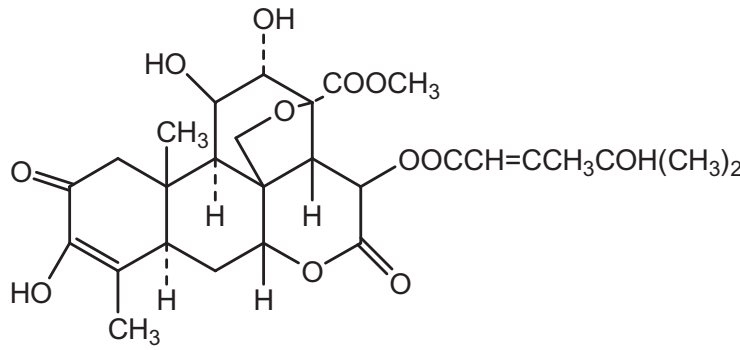

Bruceine $\mathrm{C}^{48}$

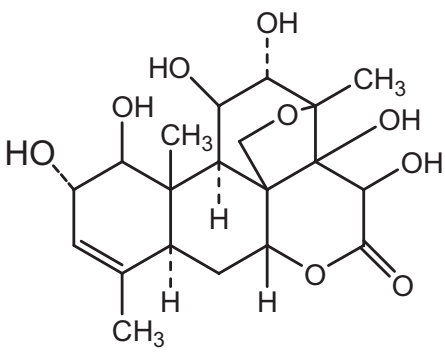

Bruceine $\mathrm{E}^{49}$

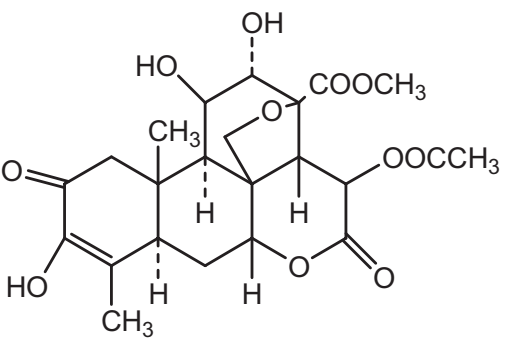

Bruceine $B^{48}$<smiles>CC1=CC(=O)C(O)C2(C)C1CC1OC(=O)C(O)C3(O)OCC2C13CO</smiles>

Bruceine $\mathrm{D}^{48}$

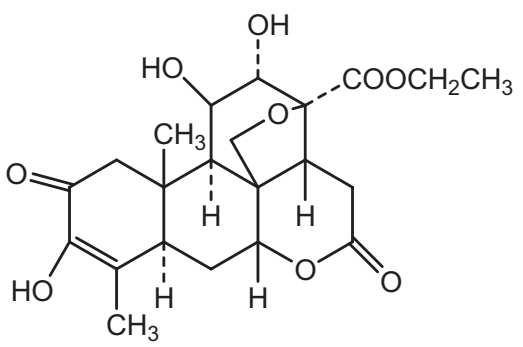

Bruceine $\left.\right|^{50}$

Figure 2 Structure of bruceine.

etiology. An ethanol-water extract of Brucea javanica relieved swelling caused by croton oil and granuloma induced by agar in a mouse ear model, indicating beneficial acute and chronic anti-inflammatory properties. ${ }^{31}$ Remarkable efficacy was also observed in a rodent model of lung inflammation caused by sporozoites and in Pneumocystis carinii pneumonia. ${ }^{32}$ Brucea javanica has also been used to prevent acute rectal inflammation and oropharyngeal mucosal inflammation induced by irradiation. However, the specific mechanism for this is not clear, so further comprehensive investigation is necessary. ${ }^{33,34}$

\section{Antiviral activity}

Brucea javanica has been used extensively to treat a variety of viral warts. It has showed significant corrosive ability in a range of wart types, including genital warts, flat warts, and corns. Flat warts are a skin disorder caused by human papillomavirus, and are amenable to treatment by Brucea javanica. This medicinal plant also triggers degeneration of tumor cells and nuclear condensation, eventually leading to cellular necrosis. ${ }^{35}$ Clinical research indicates that infusion of Brucea javanica can be used to treat vulvar condylomata, with numerous advantages, including a rapid onset of action, convenience, low toxicity, and minimal irritation of the mucosal skin. Taking these favorable characteristics into consideration, Brucea javanica has a promising future in therapeutics. ${ }^{36}$

\section{Nanoparticulate drug delivery systems}

There are two advantages of using nanoparticulate drug delivery systems in Chinese medicine. One is that nanoparticulate drug delivery systems can prolong drug retention time, and the other is that they can control drug distribution in the body. Both advan- 


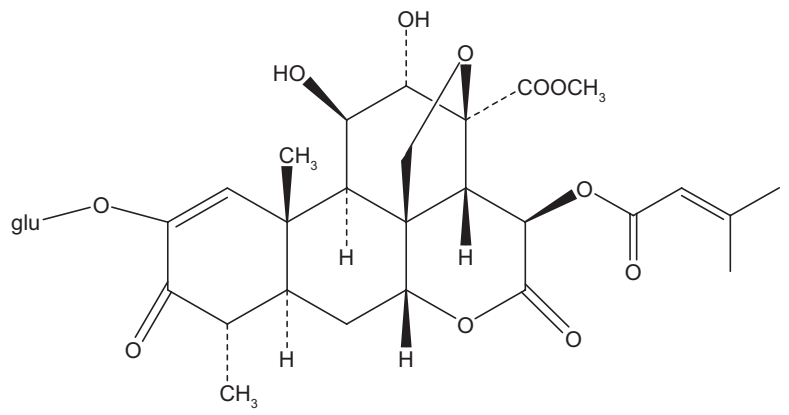

Bruceoside $\mathrm{A}^{48}$

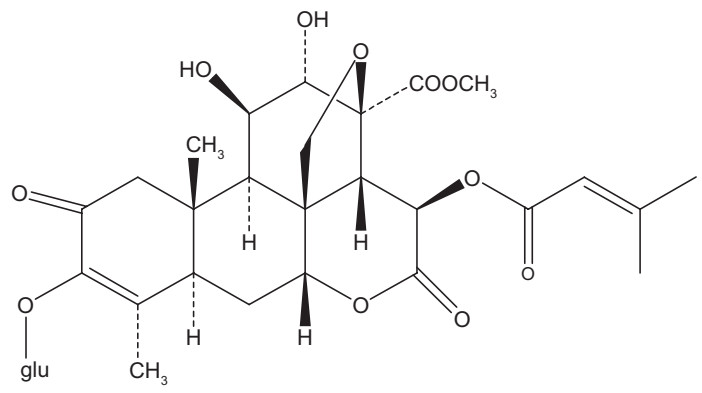

Bruceoside $\mathrm{B}^{13}$

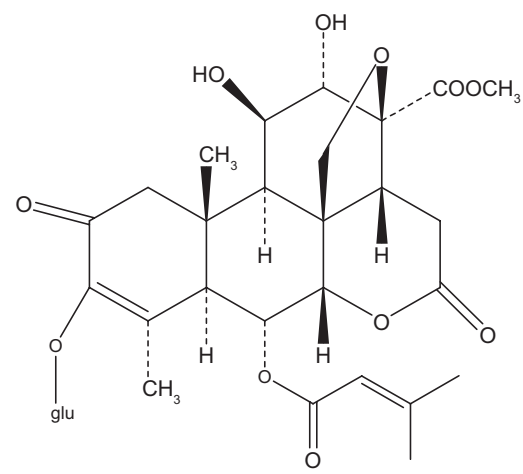

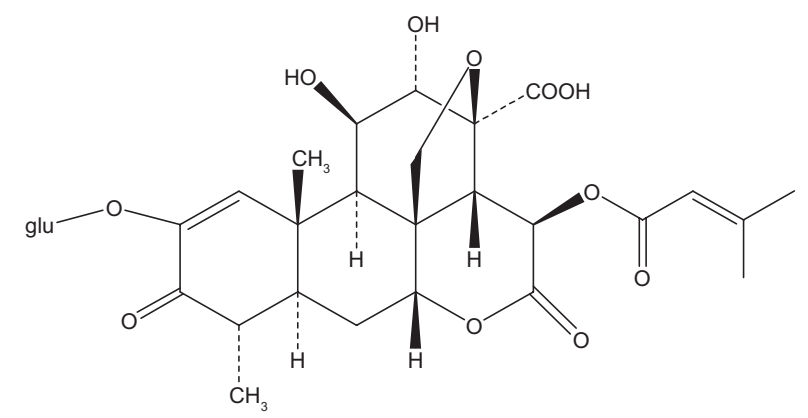

\section{Bruceoside $\mathrm{D}^{48}$}

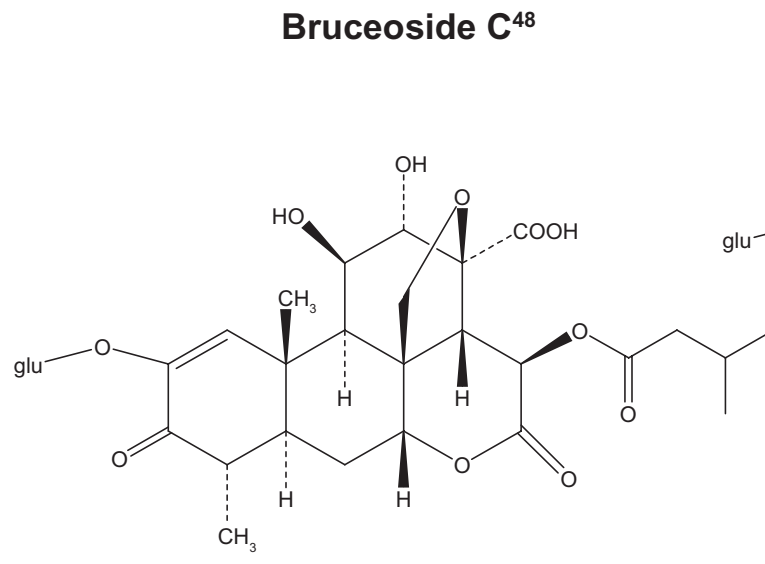

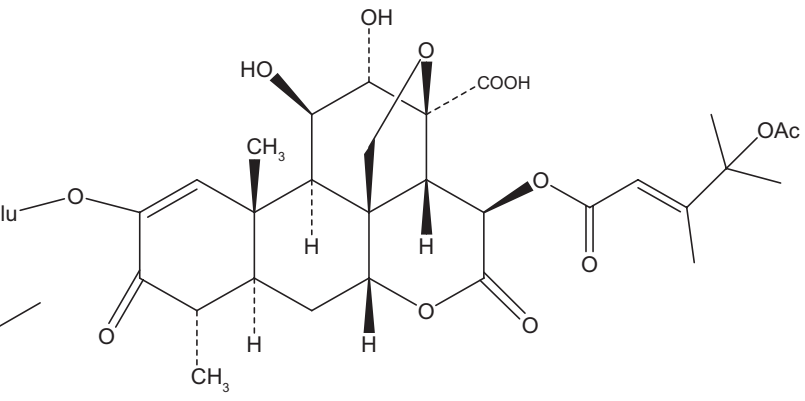

Bruceoside $\mathrm{F}^{48}$

\section{Bruceoside $\mathrm{E}^{40}$}

Figure 3 Structure of Bruceoside.

tages are beneficial for prolonging exposure time, increasing drug efficacy, reducing side effects, and overcoming the poor bioavailability of the main active components in Brucea javanica caused by poor water solubility. Presently, there are several nanoparticulate drug delivery systems for Brucea javanica, including liposomes, microemulsions, and nanoparticles.

\section{Liposomes}

A liposome is a microvesicle formed by a lipid bilayer and drug encapsulation. As a nanoparticulate drug delivery system, liposomes efficiently improve poor solubility by dissolving drugs, and generally has become a hot topic among researchers. The main components of the liposome, ie, phospholipids and cholesterol, are amphiprotic substances, which can not only encapsulate water-soluble drugs via a hydrophilic layer but also contain fatsoluble drugs via lipophilic materials. In this way, liposomes can enhance the water solubility and bioavailability of a hydrophobic drug. Furthermore, liposomes can reduce the effective drug dose and minimize toxicity, enabling a sustained therapeutic effect and improved safety. Xu et al identified that the optimal ratio of Brucea javanica oil to blank liposomes was 2.4:10 when manufacturing a freeze-dried solid liposomal powder of Brucea 
javanica.$^{37}$ Other researchers combined membrane dispersal with freeze-drying technology in order to prepare a freeze-dried powder. Drug loading was 3.6\% and encapsulation efficiency reached $92.4 \%$. The stability of the freeze-dried product was quite good and when compared with injection of the oil emulsion, the liposomes containing Brucea javanica oil had stronger antitumor activity with less toxicity. ${ }^{38}$ Further, some researchers have reported the effect of these liposomes on human hepatoma cells, indicating that they inhibited proliferation of HepG2 cells and induced apoptosis, which suggests good potential for liposomal Brucea javanica in antineoplastic therapy. ${ }^{39}$

\section{Microemulsions}

A self-emulsifying drug delivery system, such as a microemulsion, is a thermodynamically stable transparent solution which includes a drug, an oil phase, and nonionic surfactants. Broadening the contact area of the drug in the gastrointestinal tract, improving the bioavailability of hydrophobic drugs, and being able to serve as a carrier for a sustained controlled-release preparation, are all significant properties of self-emulsifying drug delivery systems. In addition, a microemulsion can mask the bad taste of a drug and improve its palatability. Researchers have identified that the optimal ratio of Brucea javanica oil to its excipients (Drug/Tween-80/TGFA) is 1:4:1 in terms of quality and stability. ${ }^{40}$ Peng et al used the single factor method to find the optimal preparation method, and concluded that a temperature under $40^{\circ} \mathrm{C}$ is key to the stability of a microemulsion. ${ }^{41}$ Other researchers explored the effect of several other components on quality, using soya lecithin as the surfactant, dioctanoyldecanoylglycerol as the oil phase, alcohol as the surfactant, and achieved enhanced bioavailability for an oral Brucea javanica oil microemulsion. ${ }^{42}$ Further pharmacokinetic research showed that it took 6 hours to reach peak plasma drug concentrations after administration of a Brucea javanica oil microemulsion. This slow-release process indicated the feasibility of developing a controlled-release preparation. ${ }^{43}$ Briefly, a microemulsion is characterized by targeted activity, a prolonged duration of action, and enhanced efficacy. Other researchers have reported that emulsifiers consisting of two thirds yolk lecithin and one third Poloxamer 188 show better stability with no delamination when centrifuged at $4000 \mathrm{rpm}$ for 15 minutes. ${ }^{44}$

\section{Nanoparticles}

Nanoparticles have two possible shapes, ie, nanocapsules and nanospheres, both of which can be formed by natural, semisynthetic, or synthetic high-polymer material with a particle size between $10 \mathrm{~nm}$ and $100 \mathrm{~nm}$. These particles show higher drug loading, a remarkable targeting effect, controlled release, and high stability, all warranting further research effort. Membrane-ultrasonic dispersion is a common method used for preparation of nanoparticles. Some researchers are using this method to produce solid nanoparticles with an entrapment efficiency of $82 \%$ and average particle size of $94 \mathrm{~nm}$, accompanying with outstanding stability, and improved patient compliance with treatment. ${ }^{45}$

\section{Other formulations}

Emulsion and microencapsulation technology can also be used to improve water solubility and bioavailability. Gas chromatography has been utilized to determine the oleic acid and linoleic acid content in a microencapsulated preparation of Brucea javanica oil. ${ }^{46}$ Beyond that, the features of a colon drug delivery system were investigated to prepare a soft Brucea javanica oil capsule using a coating technique in order to release the drug into the colon. ${ }^{47}$

\section{Looking into the future}

In recent years, as researchers have steadily intensified their study on antitumor mechanisms, Brucea javanica has been gradually arousing the interest of pharmacologists. However, various properties of Brucea javanica, including its water solubility, stability, and bioavailability are inadequate for it to be an effective treatment of cancer. Therefore, how to solve these problems and improve the curative properties of this medicinal plant are likely to become hot topics in the future. Some points are particularly important and should be noted. First, there is a need for further research on the active ingredients of Brucea javanica and the activated monomer mechanism. Second, it is necessary to separate and purify the active ingredients and the monomer. Third, we need to study the distribution and metabolism of the active ingredients in vivo. Last is the need to develop new nanoparticulate formulations for clinical use. With further investigation, Brucea javanica, one of the most active traditional Chinese medicines with significant antitumor activity, could be more widely used in the clinic and helpful to human health.

\section{Acknowledgments}

This study was supported by the Research Fund of the University of Macau (MYRG 208 (Y2-L4)-ICMS11WYT, UL016/09-Y4/CMS/WYT01/ICMS). We also thank the National Natural Science Foundation of China for its financial support (81001643, 30901547, 2010DFA32660).

\section{Disclosure}

The authors report no conflicts of interest in this work. 


\section{References}

1. Wei YJ, Qi LW, Li P, Luo HW, Yi L, Sheng LH. Improved quality control method for Fufang Danshen preparations through simultaneous determination of phenolic acids, saponins and diterpenoid quinones by HPLC coupled with diode array and evaporative light scattering detectors. $J$ Pharm Biomed Anal. 2007;45(5):775-784.

2. State Pharmacopoeia Commission. Pharmacopoeia of the People's Republic of China. Beijing, China: Chinese Medical Science and Technology Press; 2010.

3. Lau ST, Lin ZX, Zhao M, Leung PS. Brucea javanica fruit induces cytotoxicity and apoptosis in pancreatic adenocarcinoma cell lines. Phytother Res. 2008;22(4):477-486.

4. Lou GG, Yao HP, Xie LP. Brucea javanica oil induces apoptosis in T24 bladder cancer cells via upregulation of caspase-3, caspase-9, and inhibition of NF-kappaB and COX-2 expressions. Am J Chin Med. 2010;38(3):613-624.

5. Yang LH, Shi WJ, Zhao XQ. Research progress on the anti-tumor effect of Brucea. J Mudanjiang Univ. 2010;31(5):65-67. Available from: http:// www.cnki.net/KCMS/detail/detail.aspx?QueryID=0\&CurRec $=1 \& \mathrm{recid}$ $=\&$ filename $=$ MDJB201005031 $\&$ dbname $=$ CJFD2010 $\&$ DbCode $=$ CJFQ \&urlid=\&yx=\&uid=WEEvREcwSlJHSldSdnQ1 WmlIbzhpY31OeEdPW kZvV1BZRHRDVk5TTFdkMmcvanlhaDNvcFlGM1lienkzMjNrPQ.

6. Xie HY, Deng HN, Huang SX, Wu Z, Zhang M. Research on chemical ingredients of Brucea javanica. J Chin Med Mate. 1998;21(8):398-400. Available from: http://www.cnki.net/KCMS/detail/detail.aspx?QueryI $\mathrm{D}=10$ \&CurRec $=39$ \&recid $=\&$ filename $=$ ZYCA199808011\&dbname $=$ CJFD1998\&DbCode $=$ CJFQ\&urlid $=\& y x=\& u i d=$ WEEvREcwSlJHSld SdnQ1 WmlIbzhpY31OeEdPWkZvV1BZRHRDVk5TTFdkMmcvanlhaDNvcFlGM1lienkzMjNrPQ.

7. Chen H, Bai J, Fang ZF, et al. Indole alkaloids and quassinoids from the stems of Brucea mollis. J Nat Prod. 2011;74(11):2438-2445.

8. Wang HW, Liu YQ, Yan ZJ, Wei SL, Ye JQ. A gas chromatography-mass spectrometry analysis of the essential oils from Brucea javanica extracted with different methods. Fine Chemicals. 2011;28(7):668-697. Available from: http://www.cnki.net/KCMS/detail/detail. aspx?QueryID=16\&CurRec $=1 \& \mathrm{recid}=\&$ filename $=$ JXHG201107012 $\&$ dbname $=$ CJFD2011\&DbCode $=$ CJFQ \&urlid $=\& y x=\& u i d=$ WEEvRE cwS1JHSldSdnQ1 WmlIbzhpY31OeEdPWkZvV1BZRHRDVk5TTFdk MmcvanlhaDNvcFlGM1lienkzMjNrPQ.

9. Chen YY, Pan QD, Li DP, et al. New pregnane glycosides from Brucea javanica and their antifeedant activity. Chem Biodivers. 2011; $8(3): 460-466$.

10. Liu JQ, Wang CF, Li XY, Chen JC, Li Y, Qiu MH. One new pregnane glycoside from the seeds of cultivated Brucea javanica. Arch Pharm Res. 2011;34(8):1297-1300.

11. Chen QJ, Ouyang MA, Tan QW, Zhang ZK, Wu ZJ, Lin QY. Constituents from the seeds of Brucea javanica with inhibitory activity of tobacco mosaic virus. J Asian Nat Prod Res. 2009;11(6):539-547.

12. Nakao R, Mizukami C, Kawamura Y, et al. Evaluation of efficacy of bruceine A, a natural quassinoid compound extracted from a medicinal plant, Brucea javanica, for canine babesiosis. JVet Med Sci. 2009;71(1):33-41.

13. Kim IH, Hitotsuyanagi Y, Takeya K. Quassinoid glucosides from seeds of Brucea amarissima. Phytochemistry. 2004;65(23): 3167-3173.

14. Duncan GR, Henderson DB. Bruceines from Brucea sumatrana: the structure of bruceine G. Experientia. 1968;24(8):768-769.

15. Lee KH, Hayashi N, Okano M, Nozaki H, Ju-Ichi M. Antitumor agents, 65. Brusatol and cleomiscosin-A, antileukemic principles from Brucea javanica. J Nat Prod. 1984;47(3):550-551.

16. Kitagawa I, Mahmud T, Simanjuntak P, Hori K, Uji T, Shibuya H. Indonesian medicinal plants. VIII. Chemical structures of three new triterpenoids, bruceajavanin A, dihydrobruceajavanin A, and bruceajavanin $B$, and a new alkaloidal glycoside, bruceacanthinoside, from the stems of Brucea javanica (Simaroubaceae). Chem Pharm Bull (Tokyo). 1994;42(7):1416-1421.

17. Kim IH, Takashima S, Hitotsuyanagi Y, Hasuda T, Takeya K. New quassinoids, javanicolides $\mathrm{C}$ and $\mathrm{D}$ and javanicosides $\mathrm{B}-\mathrm{F}$, from seeds of Brucea javanica. J Nat Prod. 2004;67(5):863-868.
18. Chang YT. Yatanoside, a crystalline bitter principle of ya-tan-tzu, kosam or Brucea sumatrana; a review of literature, with a note on its action in vitro and in naturally infected monkeys. Chin Med J. 1951;69(3-4):87-106.

19. Fukamiya N, Okano M, Tagahara K, Aratani T, Muramoto Y, Lee KH. Antitumor agents, 90. Bruceantinoside C, a new cytotoxic quassinoid glycoside from Brucea antidysenterica. J Nat Prod. 1987;50(6):1075-1079.

20. Fukamiya N, Okano M, Tagahara K, Aratani T, Lee KH. Antitumor agents, 93. Bruceanol C, a new cytotoxic quassinoid from Brucea antidysenterica. J Nat Prod. 1988;51(2):349-352.

21. Ohnishi S, Fukamiya N, Okano M, Tagahara K, Lee KH. Bruceosides $\mathrm{D}, \mathrm{E}$, and $\mathrm{F}$, three new cytotoxic quassinoid glucosides from Brucea javanica. J Nat Prod. 1995;58(7):1032-1038.

22. Sakaki T, Yoshimura S, Tsuyuki T, Takahashi T, Honda T. Yadanzioside P, a new antileukemic quassinoid glycoside from Brucea javanica (L.) Merr with the 3-O-(beta-D-glucopyranosyl)bruceantin structure. Chem Pharm Bull (Tokyo). 1986;34(10):4447-4450.

23. Su BN, Chang LC, Park EJ, et al. Bioactive constituents of the seeds of Brucea javanica. Planta Med. 2002;68(8):730-733.

24. Ding CR, Suo YR. Progress in chemical composition and pharmacological research of Chinese medicine Brucea. Chin Trad Patent Med. 2006; 28(1):117-120. Available from: http://www.cnki.net/KCMS/detail/ detail.aspx?QueryID=22\&CurRec $=11 \&$ recid $=\&$ filename $=$ ZCYA2006 $01038 \&$ dbname $=$ cjfd2006 $\&$ DbCode $=$ CJFQ \&urlid $=\& y x=\&$ uid $=$ WEE vREcwS1JHSldSdnQ1 WmlIbzhpY31OeEdPWkZvV1BZRHRDVk5TTFdkMmcvanlhaDNvcFlGM1lienkzMjNrPQ.

25. Tian GY, Xie RH. Experimental study on the anticancer effect of extract of Brucea javanica on mice of S180. Anti-tumor Pharmacy. 2011;1(3):220-222. Available from: http://www.cnki.net/KCMS/detail/ detail.aspx?QueryID $=29 \&$ CurRec $=1 \&$ recid $=\&$ filename $=$ LIYX201103 020\&dbname $=$ CJFD2011 \&DbCode $=$ CJFQ \&urlid $=\& y x=\& u i d=W E E v$ REcwS1JHSIdSdnQ1 WmlIbzhpY31OeEdPWkZvV1BZRHRDVk5TTFdkMmcvanlhaDNvcFlGM1lienkzMjNrPQ.

26. Chen D, Chen P, Zhu M, et al. Reverse effect of Brucea javanica oil emulsion on drug resistant human ovarian carcinoma cell A2780/ DDP. J Emergency Trad Chin Med. 2009;18(4):598-599. Available from: http://www.cnki.net/KCMS/detail/detail.aspx?QueryID=34\& CurRec $=59 \&$ recid $=\&$ filename $=$ ZYJZ200904057\&dbname $=$ CJFD20 09\&DbCode $=$ CJFQ \&urlid $=\& y x=\& u i d=$ WEEvREcwSlJHSldSdnQ1 WmlIbzhpY31OeEdPWkZvV1BZRHRDVk5TTFdkMmcvanlhaDNvcFlGM1lienkzMjNrPQ.

27. Tian CT, Han LY. Inhibition of Brucea javanica oil emulsion on the proliferation of human liver cancer cell SMMC-7721 cells in vitro. Modern Oncology. 2010;18(4):654-655. Available from: http:/www.cnki.net/ $\mathrm{KCMS} /$ detail/detail.aspx?QueryID $=40 \& \mathrm{CurRec}=1 \& \mathrm{recid}=\&$ filename $=$ SXZL201004011\&dbname $=$ CJFD2010\&DbCode $=$ CJFQ\&urlid $=\&$ yx=\&uid=WEEvREcwS1JHSldSdnQ1 WmlIbzhpY31OeEdPWkZvV1BZRHRDVk5TTFdkMmcvanlhaDNvcFlGM1lienkzMjNrPQ.

28. Sun B, Wu YN, Wang SN, Qiao MM, Zhang YP. Preliminary studies on anti-proliferative effect of Brucea javanica on the human gastric cancer cell SGC-7901. Shanghai Med J. 2001;24(8):481-483. Available from: http:// www.cnki.net/KCMS/detail/detail.aspx?QueryID $=64 \&$ CurRec $=7 \& \mathrm{recid}=$ \&filename $=$ SHYX200108012\&dbname $=$ cjfd2001\&DbCode $=$ CJFQ\&url $\mathrm{id}=\& \mathrm{yx}=\&$ uid=WEEvREcwS1JHSldSdnQ1 WmlIbzhpY31OeEdPWkZvV1BZRHRDVk5TTFdkMmcvanlhaDNvcFlGM1lienkzMjNrPQ.

29. Zhang H, Yang JY, Zhou F, et al. Seed oil of Brucea javanica induces apoptotic death of acute myeloid leukemia cells via both the death receptors and the mitochondrial-related pathways. Evid Based Complement Alternat Med. 2011:965016.

30. Hu MW, Yao YW, Wang HQ. Chemotherapy efficacy and immune function of Brucea oil emulsion on 43 cases of lung cancer. J Pract Oncol. 2011;26(3):306-308. Available from: http://www.cnki.net/KCMS/ detail $/$ detail.aspx QueryID $=70 \&$ CurRec $=6 \&$ recid $=\&$ filename $=$ SY ZZ201103036\&dbname $=$ CJFD2011\&DbCode $=$ CJFQ\&urlid $=\& y$ $\mathrm{x}=$ \&uid=WEEvREcwS1JHSldSdnQ1 WmlIbzhpY31OeEdPWkZvV1BZRHRDVk5TTFdkMmcvanlhaDNvcFlGM1lienkzMjNrPQ.

31. Yang Q, Lv LL, Zhang LM, Sun R. Study on anti-inflammatory effect and adjoint toxical and side effects of different extract from Fructus Bruceae. Chin Pharmacovigilance. 2011;8(6):336-338. 
32. Qin YH, Dai XD, Zheng LL, Tao L, Cui Y. Therapeutic effect of Brucea javanica and Fructus psoraleae on Pneumocystis carinii pneumonia in rat. Chung Kuo Yao Hsueh Tsa Chih. 2007;42(4):260-263. Available from: http://www.cnki.net/KCMS/detail/detail.aspx?QueryID=92\&C urRec $=33 \&$ recid $=\&$ filename $=$ ZGYX200704006 \&dbname $=$ cjfd 2007 $\&$ DbCode $=$ CJFQ \&urlid $=\& y x=\& u i d=$ WEEvREcwSIJHSldSdnQ1 W mlIbzhpY31OeEdPWkZvV1BZRHRDVk5TTFdkMmcvanlhaDNvcF 1GM1lienkzMjNrPQ.

33. Wang HL, Lu XH. Clinical research for the prevention on acute radiation proctitis of Brucea Javanica oil emulsion. Jiangxi J Trad Chin Med. 2006;37(8):22-23

34. Wang HL, Wang YH, Weng XR, et al. Clinical research about prevention on acute radiation-induced oropharyngeal mucositis of Brucea Javanica oil emulsion. Jiangxi J Trad Chin Med. 2006;37(7):26-28. Available from: http://www.cnki.net/KCMS/ detail/detail.aspx?QueryID $=104 \&$ CurRec $=26 \& \mathrm{recid}=\&$ filename $=$ JXZY200607015\&dbname $=$ cjfd2006\&DbCode $=$ CJFQ\&urlid=\&y $\mathrm{x}=$ \&uid=WEEvREcwSlJHSldSdnQ1 WmlIbzhpY31OeEdPWkZvV1BZRHRDVk5TTFdkMmcvanlhaDNvcFlGM1lienkzMjNrPQ.

35. Liu H. Verruca plana treatment of Brucea. Chin Nurs Res. 2007;21 (6):1533. Available from: http://www.cnki.net/KCMS/detail/detail.a spx?QueryID $=110 \&$ CurRec $=26 \&$ recid $=\&$ filename $=\mathrm{SXHZ2007170}$ $16 \&$ dbname $=$ cjfd2007\&DbCode $=\mathrm{CJFQ} \&$ urlid $=\& y x=\& u i d=$ WEEv REcwSlJHSldSdnQ1 WmlIbzhpY31OeEdPWkZvV1BZRHRDVk5TTFdkMmcvanlhaDNvcFlGM1lienkzMjNrPQ.

36. Sun JM, Feng SL, Zhou PH. Chinese medicine Brucea infusion treatment of 34 cases of vulvar condyloma. China Pract Med. 2010;5(20):156. Available from: http://www.cnki.net/KCMS/detail/detail.aspx?QueryI $\mathrm{D}=117 \&$ CurRec $=1 \&$ recid $=\&$ filename $=$ ZSSA201020116\&dbname $=\mathrm{CJ}$ FD2010\&DbCode $=$ CJFQ\&urlid $=\& y x=\& u i d=$ WEEvREcwS1JHSldSdn Q1 WmlIbzhpY31OeEdPWkZvV1BZRHRDVk5TTFdkMmcvanlhaDNvcFlGM1lienkzMjNrPQ.

37. Xu L. Pharmacy Behavior Investigation and Preparation of Oleum Fructus Brucea Freeze-dried Lipsome. Yangzhou, China: Yangzhou University; 2008. Available from: http:/www.cnki.net/KCMS/ detail/detail.aspx?QueryID $=127 \&$ CurRec $=58 \&$ recid $=\&$ filenam $\mathrm{e}=2008087124$. nh $\&$ dbname $=$ CMFD2009 $\&$ DbCode $=$ CMFD $\&$ urlid $=$ \&yx=\&uid=WEEvREcwSlJHSldSdnQ1 WmlIbzhpY31OeEdPWkZvV1BZRHRDVk5TTFdkMmcvanlhaDNvcFlGM1lienkzMjNrPQ.

38. Cui Y, Wu Z, Liu X, et al. Preparation, safety, pharmacokinetics, and pharmacodynamics of liposomes containing Brucea javanica oil. AAPS Pharm Sci Tech. 2010;11(2):878-884. Available from: http://www. ncbi.nlm.nih.gov/pubmed?term=Preparation $\% 2 \mathrm{C} \% 20$ safety $\% 2 \mathrm{C} \% 20$ pharmacokinetics \%2C\%20and \%20pharmacodynamics\%20of\%20 liposomes $\% 20$ containing $\% 20$ Brucea $\% 20$ javanica $\% 20$ oil.

39. Shi L, Yue Y, Wang ZR. Suppression of human hepatocellular cancer cell line HepG2 by Brucea liposome in vitro and in vivo. J Xi'an Jiaotong University (Medical Sciences). 2011;32(6):772-777.

40. Liu Y, Li GD, Liu CC. Recipe for self-emusifying preparation of Brucea javanica seed oil. Acad J Second Mil Med Uni. 2009;30 (9):1069-1073. Available from: http://www.cnki.net/KCMS/detail/detail.aspx?QueryID $=161 \&$ CurRec $=32 \&$ recid $=\&$ filename $=$ DEJD200909027\&dbname $=$ CJ FD2009\&DbCode $=$ CJFQ\&urlid $=\& y x=\& u i d=$ WEEvREcwSlJHSldSdn Q1 WmlIbzhpY31OeEdPWkZvV1BZRHRDVk5TTFdkMmcvanlhaDNvcFlGM1lienkzMjNrPQ.

41. Peng XH, Cui MQ, Ci ZM, Fu CM, Zheng SH. Research in prescription of self-emulsifying drug delivery system for Brucea oil. Chinese Trad Patent Med. 2011;33(9):1520-1524. Available from: http://www.cnki. net/KCMS/detail/detail.aspx?QueryID=168\&CurRec=1\&recid=\&filen ame $=$ ZCYA201109018\&dbname $=$ CJFD2011\&DbCode $=$ CJFQ\&urlid $=\& y x=\& u i d=W E E v R E c w S 1 J H S l d S d n Q 1 \mathrm{WmlIbzhpY31OeEdPWkZv-}$ V1BZRHRDVk5TTFdkMmcvanlhaDNvcFlGM1lienkzMjNrPQ.
42. Zhang KP, Lin SZ, Chen GG, Li XM. The preparation and stability study of Brucea javanica oil microemulsion. West China J Pharm Sci. 2005;20(3):199-201. Available from: http://www.cnki.net/KCMS/ detail/detail.aspx?QueryID $=173 \&$ CurRec $=20 \&$ recid $=\&$ filename $=H$ XYO200503005\&dbname $=$ CJFD2005\&DbCode $=$ CJFQ\&urlid $=\& y x=$ \&uid=WEEvREcwS1JHSldSdnQ1 WmlIbzhpY31OeEdPWkZvV1BZRHRDVk5TTFdkMmcvanlhaDNvcFlGM1lienkzMjNrPQ.

43. Xiang Q, Zhou LL, Zhang H, Zhang HB, Yao CS, Huang YD. In vivo pharmacokinetic studies of Brucea oil microemulsion in rat. J Chin Med Mater. 2007;30(9):1113-1115. Available from: http:// www.cnki.net/KCMS/detail/detail.aspx?QueryID=179\&CurRec $=14 \&$ recid $=\&$ filename $=$ ZYCA200709021 $\&$ dbname $=$ CJFD2007 $\&$ DbCode $=$ CJFQ \&urlid $=\& y x=\& u i d=$ WEEvREcwS1JHSldSdnQ1 WmlIbzhpY31OeEdPWkZvV1BZRHRDVk5TTFdkMmcvanlhaDNvcFlGM1lienkzMjNrPQ.

44. Pan W, Hu HB, Cui MC, Pan JH, Ou YQ. Research about prescription and technology of Brucea javanica oil subnanoemulsion injection. Chinese Journal of Information on TCM. 2009;16(1):63-65. Available from: http://www.cnki.net/kcms/detail/detail.aspx?dbcode=cjfq\&dbna $\mathrm{me}=$ cjfq2009\&filename $=$ xxyy200901033\&uid $=\& p=$.

45. Li H, Liu F, Li TH, Xin YJ, Zhang H. Study on preparation of Brucea Javanica oil solid nanoparticles. Shanxi J Trad Chin Med. 2009;30(2):216-217. Available from: http://www.cnki.net/KCMS/ detail/detail.aspx?QueryID $=221 \&$ CurRec $=12 \&$ recid $=\&$ filename $=\mathrm{SX}$ ZY200902068\&dbname $=$ CJFD2009\&DbCode $=$ CJFQ\&urlid=\&yx $=$ \&uid=WEEvREcwSlJHSIdSdnQ1 WmllbzhpY31OeEdPWkZvV1BZRHRDVk5TTFdkMmcvanlhaDNvcFlGM1lienkzMjNrPQ.

46. Cai B, Chen G, Wen L, Wu XY, Liu GQ, Huang XQ. Gas chromatography determination of Brucea oil microcapsules in oleic and linoleic acids. Lishizhen Mechine and Materia Medica Research. 2011;22(5):1057-1058. Available from: http://www.cnki.net/ KCMS/detail/detail.aspx?QueryID $=191 \&$ CurRec $=1 \&$ recid $=\& f i$ lename $=$ SZGY201105010\&dbname $=$ CJFD2011\&DbCode $=$ CJF Q\&urlid=\&yx=\&uid=WEEvREcwS1JHSldSdnQ1 WmlIbzhpY31OeEdPWkZvV1BZRHRDVk5TTFdkMmcvanlhaDNvcF1GM1lienkzMjNrPQ.

47. Wang JX, Li N, Gao CK. Study on preparation of $\mathrm{pH}$-sensitive colon-specific Brucea oil soft capsule. Chin Trad Patent Med. 2008; 30(12):1775-1778. Available from: http://www.cnki.net/KCMS/detail/ detail.aspx?QueryID=185\&CurRec $=1 \&$ recid $=\&$ filename $=$ ZCYA20081 $2016 \&$ dbname $=$ CJFD2008 $\&$ DbCode $=$ CJFQ \&urlid $=\& y x=\& u i d=W E E$ vREcwSlJHSldSdnQ1 WmlIbzhpY31OeEdPWkZvV1BZRHRDVk5TTFdkMmcvanlhaDNvcFlGM1lienkzMjNrPQ.

48. Guo Z, Vangapandu S, Sindelar RW, et al. Biologically active quassinoids and their chemistry: potential leads for drug design. Curr Med Chem. 2005;12(2):173-90.

49. Liu JH, Zhao N, Zhang GJ, et al. Bioactive quassinoids from the seeds of Brucea javanica. J Nat Prod. 2012;75(4):683-8.

50. Yu RM, Lin SX, Zhang WC, Li X. Research progress on quassinoid compounds from 1985 to 1993. Chinese Journal of Medicinal Chemistry. 1994;4(3):224-232. http://www.cnki.net/KCMS/detail/ detail.aspx?QueryID $=3 \&$ CurRec $=1 \&$ recid $=\&$ filename $=$ ZGYH40 $3.014 \&$ dbname $=$ CJFD 1994 $\&$ DbCode $=$ CJFQ \&urlid $=\& y x=\& u i d=$ WEEvREcwS1JHSldSdnQ0TitJZHZYajBsZ2VGRk9PbGV3czRle VZxN2pnbWFFd0hYWFN2YXEraDUrQkVBNytRPQ==. 


\section{Publish your work in this journal}

The International Journal of Nanomedicine is an international, peerreviewed journal focusing on the application of nanotechnology in diagnostics, therapeutics, and drug delivery systems throughout the biomedical field. This journal is indexed on PubMed Central, MedLine, CAS, SciSearch $\AA$, Current Contents ${ }^{\circledR} /$ Clinical Medicine,
Journal Citation Reports/Science Edition, EMBase, Scopus and the Elsevier Bibliographic databases. The manuscript management system is completely online and includes a very quick and fair peer-review system, which is all easy to use. Visit http://www.dovepress.com/ testimonials.php to read real quotes from published authors.

Submit your manuscript here: http://www.dovepress.com/international-journal-of-nanomedicine-journal 